\title{
LYON NATURAL RADIOCARBON MEASUREMENTS I
}

\author{
J. EVIN, R. LONGIN, and CH. PACHIAUDI
}

Laboratoire de Radiocarbone, Institut de Physique Nucléaire 69 - Villeurbanne, France

\section{INTRODUCTION}

The Radiocarbon Dating Laboratory was founded in 1965 by the Department of Geology, University of Lyon, to study the Late Quaternary geology of the Rhône-Alps Region, and to contribute to hydrogeologic and archaeologic studies. It has been installed in the basement of the Nuclear Physics Institute. Preparation began in 1966 and first dates obtained in June 1967.

We used proportional counters filled with pure $\mathrm{CO}_{2}$, as detectors (De Vries, 1953). During the first months of 1967, we had a quartz counter coated inside with gold (Vogel, 1967), specially built by Prof. J. C. Vogel, Radiocarbon Laboratory of Groningen. Afterwards, we changed the mounting of that type of detector and we now use two counters with an effective volume of $0.5 \mathrm{~L}$, filled at $21^{\circ} \mathrm{C}$ to a pressure of $225 \mathrm{~cm} \mathrm{Hg}$.

The counters are shielded by $10 \mathrm{~cm}$ of selected lead, $10 \mathrm{~cm}$ of boroparaffin and $3 \mathrm{~cm}$ of old lead. Anticoincidence shielding consists of two layers of 24 G.M. counters each. The electronic circuits are of commercial origin, or made in the Institute. An automatic system prints out the count rates every 100 minutes.

Backgrounds of the two detectors are respectively 4.7 and $3.8 \mathrm{cpm}$. These values do not change appreciably with barometric pressure, but a very good stability of humidity and temperature are controlled in the counting room.

The detectors yield a counting rate of 9.5 and $10.2 \mathrm{cpm}$ for $95 \%$ NBS oxalic acid standard, which is prepared by direct combustion. Determination of isotopic fractionation of this preparation has been kindly made by W. G. Mook, $\mathrm{C}^{13}$ laboratory at Groningen, who got $\delta \mathrm{C}^{13}=-19.78 \%$ PDB standard. In order to test our equipment we measured some samples sent by Prof. Vogel. We got the following results:

\section{Groningen samples}

$\begin{array}{lllr}\text { GrN-5307 } & \mathbf{1 6 0} \pm \mathbf{3 0} & \text { Ly-90 } & \mathbf{2 2 0} \pm \mathbf{1 2 0} \\ \text { GrN-5262 } & \mathbf{8 0 6 0} \pm \mathbf{6 5} & \mathbf{L y}-87 & \mathbf{7 8 4 0} \pm \mathbf{3 0 0} \\ \text { GrN-5309 } & \mathbf{1 9 , 2 4 0} \pm \mathbf{1 6 0} & \mathbf{L y}-88 & \mathbf{1 8 , 9 0 0} \pm \mathbf{5 0 0} \\ \text { GrN-5237 } & \mathbf{4 7 , 7 0 0} \pm \mathbf{2 3 5 0} & \mathbf{L y}-\mathbf{8 9} & >\mathbf{3 5 , 0 0 0}\end{array}$

Lyon measurements

All samples are counted at least twice for periods of $1200 \mathrm{~min}$. Ages are calculated using the Libby half-life value 5570 with A.D. 1950 as reference year. The statistical errors, corresponding to one standard deviation, include the contribution of the contemporary standard, background and sample counting. $\mathrm{C}^{13}$ corrections have not been carried out.

The samples are pretreated in the classic way: $\mathrm{HCl} 2 \%$ and $\mathrm{NaOH}$ 
$2 \%$. A new technique for extraction of bone-collagen is used and will be described later. $\mathrm{CO}_{2}$ is purified according to a modified De Vries method; (De Vries, 1956): $\mathrm{CO}_{2}$ passes, by thermal convection, over red copper and silver at $450^{\circ} \mathrm{C}$, and through a dry-ice trap.

\section{ACKNOWLEDGMENTS}

We are grateful to Prof. J. Flandrin and Prof. A. Sarazin for giving the opportunity to create this laboratory and for continuous support. We are indebted to many in the Nuclear Physics Institute who gave us technical help.

J. Evin would like to express his thanks to Prof. J. C. Vogel who received him in his laboratory at Groningen for six months and, especially to Mr. J. C. Lerman for his friendly teaching and advice. Finally, we thank all the staff of the $\mathrm{C}^{14}$ laboratory of Groningen.

\section{SAMPLE DESCRIPTIONS}

I. GEOLOGIC SAMPLES

\section{Chamagnieu series, Isère}

Samples from peat bog in Bourbre R. valley, at Les Cariaux near Chamagnieu, Isère (45 $39^{\prime} \mathrm{N}$ Lat, $5^{\circ} 9^{\prime} \mathrm{E}$ Long). Coll. 1966 by J. Evin.

\section{Ly-36. Chamagnieu I}

Peat from 30 to $40 \mathrm{~cm}$ below surface.

\section{Ly-13. Chamagnieu II}

Peat from 70 to $80 \mathrm{~cm}$ below surface.

\section{Ly-91. Chamagnieu III}

Wood found in peat $150 \mathrm{~cm}$ below surface.

\section{$1800 \pm 200$ \\ A.D. 150}

$$
2200 \pm 100
$$

250 B.C.

$$
2780 \pm 160
$$

830 B.C.

\section{Ly-92. Chamagnieu IV}

$4040 \pm 400$

Humus fraction of below surface.

General Comment: pollen analysis has been done on these samples. Growth rate may be compared with other peat bogs (Oeschger, 1965).

\section{Ly-34. Le Vernay, Isère}

$4070 \pm 120$

2120 B.C.

From bore hole at Le Vernay near Ruy Isère $\left(45^{\circ} 34^{\prime} \mathrm{N}\right.$ Lat, $5^{\circ} 19^{\prime}$ E Long). Coll. 1966 and subm. by A. Peguin, 35 Rue Arago, VilleurbanneRhône. Comment: date may be compared with Ly-92, in same valley
$10 \mathrm{~km}$ below. 


\section{Ly-24. Veyrins, Isère}

From bore hole at Veyrins, Isère (45 $38^{\prime} \mathrm{N}$ Lat, $5^{\circ} 32^{\prime} \mathrm{E}$ Long). Coll. 1966 and subm. by A. Peguin. Comment: boring was in alluvions of old Rhône channel.

\section{Ly-14. Gourdon, Ain}

Charred wood from gravel bank in Ain R. at Gourdon near Saint

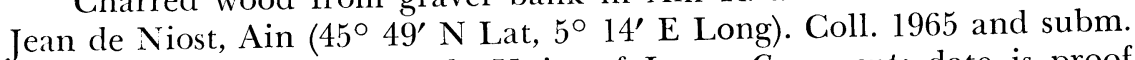
by Ph. Artru, Dept. of Geol., Univ. of Lyon. Comment: date is proof that wood comes from old continental sediments (may be late Miocene) which are carried away unaltered by river.

\section{ARCHAEOLOGIC SAMPLES}

\section{A. Historical Period}

\section{Ly-7. Vallée de Vallonge, Basses Alpes}

A.D. 1320

$630 \pm 200$

Charcoal from old lime-kiln in Vallonge R. valley near La Palud de Moutiers, Basses Alpes (43 $48^{\prime}$ N Lat, 6 ${ }^{\circ} 18^{\prime}$ E Long). Coll. 1965 and subm. by J. Flandrin. Comment (J.F.): younger than expected considering thickness of sediments overlaying kiln.

\section{Ly-25. Busserolles, Côte d'Or}

$1870 \pm 170$

Charcoal from framework of Gallo-Roman villa at Busserolles, Côte d'Or (47 $39^{\prime} \mathrm{N}$ Lat, 4 58' E Long). Coll. 1966 and subm. by R. Ratel, Dept. of Geol., Univ. of Dijon. Comment: agrees with supposed destruction time of villa: ca. A.D. 200.

\section{Ly-61. Briord 261, Ain}

$2060 \pm 200$

110 B.c.

Bones from grave in Gallo-Roman cemetery at Les Plantis near Briord, Ain (45 $46^{\prime} \mathrm{N}$ Lat, $5^{\circ} 27^{\prime} \mathrm{E}$ Long). Coll. 1967 and subm. by R. Perraud, Le Vanel La Mure-sur-Azergue, Rhône. Comment: agrees with Emperor Tiberius' coins found in another grave in same cemetery.

\section{B. Bronze and Neolithic Periods}

Samples from coastal stations, "Palaffites" of French alpine lakes.

\section{Chatillon series, Savoie}

Charcoal and wood from coastal sta. underlying ca. $5 \mathrm{~m}$ water in $\mathrm{N}$ part of Le Bourget Lake at Chatillon near Chindrieux, Savoie $\left(45^{\circ} 46^{\prime}\right.$ $\mathrm{N}$ Lat, 5 $5^{\circ} 50^{\prime} \mathrm{E}$ Long). Coll. 1966 and 1967 and subm. by R. Laurent, Centre de Recherches Archéolog. Lacustres, Tresserves, Savoie.

\section{Ly-18. Chatillon 85 AI}

$2730 \pm 160$

Wood from hearth. 


\section{Ly-17. Chatillon 85 A2}

Wood supposedly from hut.

\section{Ly-9. Chatillon 85 A3}

$3060 \pm 100$

Wood from inner part of large pile foundation.

1110 B.C.

General Comment: as expected Ly-9 is slightly old

Ly-17. These 3 dates agree well Ly-9 is slightly older than Lv-18 and assoc. Late Bronze industry.

\section{Ly-20. Aiguebelette 219 A2, Savoie \\ $4150 \pm 180$ \\ Wood from pile foundation of} water in Aiguebelette Lake, near Saastal sta. underlying ca. $5 \mathrm{~m}$ of $5^{\circ} 48^{\prime}$ E Long). Coll. 1966 and subm.-Alban, Savoie $\left(45^{\circ} 34^{\prime} \mathrm{N}\right.$ Lat, much older than Ly-19 and Gif-202 from 2 other coastal sta in $S$ part of $12480 \pm 150$ B.P.) which were taken

\section{Ly-19. Aiguebelette 219 A3, Savoie $\quad 3040 \pm 140$ \\ Wood from pile foundation of coasta}

of Aiguebelette Lake near Saint-Albastal sta. submerged in SW part saint-Alban, Savoie $\left(45^{\circ} 32^{\prime} \mathrm{N}\right.$ Lat, $5^{\circ} 47^{\prime}$ 222 which comes from anoth. by R. Laurent. Comment: closer to Gif-

\section{Ly-63. Sévrier 267 AI, Haute-Savoie $\quad 3400 \pm 600$}

Small fragments of handle of a bronze

submerged in Lake of Annde of a bronze dagger found in coastal sta. $6^{\circ} 9^{\prime} \mathrm{E}$ Long) (Laurent, Comment: agrees with supposed Coll. 1967 and subm. by R. Laurent. statistical error.

\section{Neolithic and Paleolithic Periods}

\section{Ly-48. Peylenc, Haute-Loire}

$1950 \pm 190$

Charcoal from supposed Paleolithic

Eynac, Haute-Loire $\left(45^{\circ} 38^{\prime}\right.$ Neolithic site at Peylenc near Saint-Pierre, 1966). Coll. 1966 and subm. $\mathrm{N}$ Lat, $4^{\circ} 12^{\prime} \mathrm{E}$ Long) (Bayle des Hermens, sur Gazeille, Haute-Loire Co A. Crémilleux, 6 Rue Faget, Le Monastier of overlying levels and mixing of : this value confirms suspected sliding

\section{Ly-82. Le Rond du Lévrier, Haute-Loire \\ $4750 \pm 300$}

Charcoal from level underlying

Hallstatt grave at Abri du Rond Coll. 1967 and subm. by A Crémile (44 $51^{\prime} \mathrm{N}$ Lat, $3^{\circ} 58^{\prime} \mathrm{E}$ Long). but in good agreement with Ly-50. 
Ly-50. La Baume, Loire, Haute-Loire

Charcoal from Layer 80 at Abri de la Baume, Loire near Solignac, Haute-Loire ( $44^{\circ} 56^{\prime} \mathrm{N}$ Lat, $3^{\circ} 54^{\prime}$ E Long). Coll. 1966 and subm. by A. Crémilleux. Comment: agrees with assoc. Neolithic industry.

\section{Seuil des Chèvres series, Savoie}

Charcoal from site occupied from Upper Paleolithic until Roman time in Seuil des Chèvres grotto near La Balme, Savoie $\left(45^{\circ} 41^{\prime} \mathrm{N}\right.$ Lat, $5^{\circ} 21^{\prime}$ E Long) (Vanbrugghe, 1968). Coll. 1967 and subm. by R. Vanbrugghe, 55 Rue C. Desmoulins, Hellemes Nord.

\section{Ly-69. Seuil des Chèvres D7}

$$
5240 \pm 100
$$

Charcoal from Layer IV. Comment: agrees with assoc. Neolithic industries.

$$
8980 \pm 400
$$

Ly-70. Seuil des Chèvres E6

Small bits of charcoal scattered in Layer V. Comment: assoc. with cold fauna of elks and marmots.

\section{Ly-16. Les Romains, Savoie}

$14,380 \pm 380$

Small bits of charcoal from Magdalenian site at La Grotte des Romains near Virignien, Ain $\left(45^{\circ} 41^{\prime} \mathrm{N}\right.$ Lat, $5^{\circ} 21^{\prime}$ E Long). Coll. and subm. 1967 by R. Desbrosses, Les Sapins, Blanzy, Saône et Loire. Comment: in general agreement with industry despite fact that sample was sifted from great volume of sediments.

\section{WATER SAMPLES}

The following samples were coll. and measured in a general study of the Fontaine de Vaucluse. (Evin, 1968) The reservoir of this huge intermittent spring in a tributary to the Rhône is a calcareous region with an area of several hundred sq. $\mathrm{km}$.

\section{Ly-29. Fontaine de Vaucluse, Source principale \\ $\delta \mathbf{C}^{14}=\mathbf{9 1 . 5} \pm \mathbf{3 \%}$ \\ Water from main spring (43 $54^{\prime} \mathrm{N}$ Lat, $5^{\circ} 7^{\prime} \mathrm{E}$ Long). Coll. April, 1967 by J. Evin. Comment: this water was drawn during low-water stage; the spring had not been flowing since February.}

\section{Ly-30. Fontaine de Vaucluse, Source$$
\text { secondaire }
$$$$
\delta \mathrm{C}^{14}=\mathbf{9 3 . 7} \pm \mathbf{3 \%}
$$

Water from small spring. Coll. April, 1967 by J. Ervin. Comment: this spring is perennial.

\section{Ly-15. Salignan, Vaucluse}

$$
\delta \mathbf{C}^{14}=\mathbf{5 6 . 2} \pm \mathbf{2 \%}
$$

Water from well, depth $135 \mathrm{~m}$, at Salignan near Apt Vaucluse $\left(43^{\circ} 46^{\prime}\right.$ N Lat, 5० 18' E Long). Coll. July, 1966 and April, 1967 by J. Evin. 

Comment: average of 2 measurements. Unexpectedly low activity; ground
water supposedly supplied the spring directly.

\section{Ly-27. Villemoirieu, Isère}

Water from well at Villemoirieu, Isère $\delta \mathbf{C}^{14}=\mathbf{9 4 . 9} \pm \mathbf{3 \%}$

Long). Coll. April, 1967 by J. Fvin. Comère $\left(45^{\circ} 43^{\prime} \mathrm{N}\right.$ Lat, $5^{\circ} 13^{\prime} \mathrm{E}$ of calcareous reservoir at Cremieu, Isère.

\section{Ly-28. Dizimieu, Isère}

Water from well at Dizimieu, Isère $\left(45^{\circ} 42^{\prime} \quad \delta \mathbf{C}^{14}=\mathbf{1 0 0} \pm \mathbf{5 \%}\right.$

Coll. April, 1967 by J. Evin. Comment: $\left(45^{\circ} 42^{\prime} \mathrm{N}\right.$ Lat, $5^{\circ} 17^{\prime} \mathrm{E}$ Long). water body.

General Com

cluse spring water on comparing Ly-27-Ly-30, it can be seen that Vauwith water whose bicarbonates had be mixed either with old water or reservoir. Low activity of Ly-15 indicatesone isotopic exchange in one water exist at Salignan, where hydroges, however, that such types of Vaucluse spring, can only be indirect.

Date lists:

\section{REFERENCES}

$\begin{array}{ll}\text { Bern IV } & \text { Oeschger and Riesen, 1965 } \\ \text { Gif II } & \text { Delibrias, Gullier, and Labeyrie, } 1966 \\ \text { Groningen VII } & \text { Vogel and Waterbolk, 1967 }\end{array}$

Bayle des Hermens, $R$, and Cremilloux, $A$,

commune de Saint-Pierre Eynac,

Delibrias, G., Gullier, M. T., and Labeyrie, Joire: Soc. Préhist. Fr. Bull. 63, p. 208-219. ments II: Radiocarbon, v. 8, p. 74-95. J. 1966, Gif natural radiocarbon measure-

Evin, J., Flandrin, J, and M. 8, p. 74-95. congress of Hydrogeology, Istanbul, 1968, Le forage de Salignan: International Laurent, R., 1968, Apparition, Istanbul, 1967, in press. Bronze Final: Soc. linnéenne de métallurgie du fer dans les stations littorales du

Oeschger, H. and Riesen, T. 1965, Bern radiocarbon dates anée no2, p. 54-65.

Vanbrugghe, R. and Bill, I., 1968, Lern radiocarbon dates IV: Radiocarbon, v. 7, p. 1-19. Fouilles de 1967: Soc. linnéenne de Lrotte du Seuil des Chèvres à la Balme Savoie

de Vries, H. L., 1956, Purification of pure COn Bull., 37ème année $\mathrm{n}^{\circ} 4$, p. 150-158.

$\mathrm{C}^{14}$ age measurements: Appl. Sc. Res., sect. B use in a proportional counter for

de Vries, H. L. and Barendsen, Sc. Res, sect. B, 5, p. 387-400.

counter filled with carbon dioxide: 1953, Radiocarbon dating by a proportional

Vogel, J. C., 1963, The use of carbon isotopes in, 19, p. 987-1003.

in Hydrology, I.A.E.A., Vienna, p. 383-396 in ground water studies: Radio-isotopes

Vogel, J. C. and Waterbolk,

carbon, v. 9, p. 107-155. 